\title{
Teologia Praktyczna
}

\section{Uniwersytet im. Adama Mickiewicza w Poznaniu • Wydział Teologiczny}

\section{Tom 18, 2017 doi: 10.14746/tp.2017.18.06}

\section{ADAM PRZYBECKI \\ Migracja wyzwaniem dla Kościoła w Polsce}

Rosnąca gwałtownie fala migracyjna, której skutki od kilku lat w znaczący sposób odczuwa Europa, staje się szczególnym wyzwaniem nie tylko dla polityków i ekonomistów, ale także jest apelem kierowanym w stronę duszpasterstwa Kościoła. Problem ten - jak wskazują na to pierwsze doświadczenia - dotyczy również Kościoła lokalnego w Polsce, który dotychczas nie mierzył się z tak nadzwyczajnym zjawiskiem. W publikacjach zwraca się uwagę, że „dramat tego wyzwania płynie nie tylko ze wzrastającego w skali ogólnoświatowej natężenia ruchów migracyjnych i ich kierunków, ale przede wszystkim z wieloaspektowości problemów i sytuacji krańcowych, przed jakimi staje migrant tak we wspólnocie, którą opuszcza, jak i w społeczności, w której szuka możliwości zatrzymania się. Proces opuszczania rodzimej wspólnoty etnicznej, jak i przybycie «obcego-innego» do wspólnoty go przyjmującej jest wyzwaniem dla Kościoła. Kościół, jako wspólnota wielokulturowa i wielojęzyczna, zjawisko migracji i ruchliwości człowieka postrzega jako właściwe swojej naturze. Jest ono na stałe wpisane w dzieje Wspólnoty uczniów Jezusa z Nazaretu i od Dnia Jerozolimskiej Pięćdziesiątnicy ukazuje interkulturowość Chrystusowej Wspólnoty wiary, nadziei i miłości oraz dynamizuje jej misyjność"1.

Należy podkreślić, że wzbierająca fala migracyjna obejmuje zarówno migrantów, jak i uchodźców. W sytuacji coraz częstszego utożsamiania tych pojęć w przekazach mass mediów i w debacie publicznej zwrócić trzeba uwagę na zachodzącą między nimi zasadniczą różnicę o charakterze prawnym. Wią-

Adam P R Z Y B E C K I, ks. prof. dr hab., kierownik Zakładu Teologii Pastoralnej i Prawa Kanonicznego, Wydział Teologiczny UAM, Poznań, e-mail: adamfran@amu.edu.pl

${ }^{1}$ W. N e c e l: Wprowadzenie. Jesteśmy przybyszami i osadnikami. W: J a n Paw eł II: Orędzia na Światowy Dzień Migranta i Uchodźcy 1985-2005. Opr. W. Necel. Poznań 2009 s. 5. 
że się to z określonymi konsekwencjami dotykającymi zainteresowanych osób. Podstawowym kluczem do rozróżnienia obu pojęć jest powód podjęcia decyzji o opuszczeniu własnego państwa. Jako migranta określa się najczęściej osobę, która dobrowolnie przekracza granicę, np. w poszukiwaniu lepszych możliwości ekonomicznych ${ }^{2}$. Natomiast terminem ,uchodźca” Konwencja genewska z 1951 roku określa osobę, która „na skutek uzasadnionej obawy przed prześladowaniem z powodu swojej rasy, religii, narodowości, przynależności do określonej grupy społecznej lub z powodu przekonań politycznych przebywa poza granicami państwa, którego jest obywatelem, i nie może lub nie chce z powodu obaw korzystać z ochrony tego państwa, albo która nie ma żadnego obywatelstwa i znajduje się, na skutek podobnych zdarzeń, poza państwem swojego dawnego stałego zamieszkania nie może lub nie chce z powodu tych obaw powrócić do tego państwa"3.

Sytuacja, w jakiej znalazło się polskie społeczeństwo i kościelna wspólnota wobec gwałtownie postępującej od kilku lat fali migracyjnej, ukazała nieprzygotowanie ludzi do podjęcia nieznanego dotąd wyzwania. Oto słynące z gościnności i otwartości na przybyszów społeczeństwo, głównie pod wpływem agresywnej propagandy medialnej i wypowiedzi niektórych polityków, objawiło nową, jakże zaskakującą twarz. Nieustanne epatowanie informacjami o krwawych zamachach w państwach Europy Zachodniej, ukazywanie uchodźców i migrantów zarobkowych jako nosicieli chorób oraz ,różnego rodzaju pasożytów i pierwotniaków", planujących akty terrorystyczne, a także mających zniszczyć w Polsce chrześcijańską cywilizację, zrodziło w ludziach nieufność wobec przybyszy i obcych. To swoiste zarządzanie strachem i ludzkimi lękami ${ }^{4}$ spowodowało również zamknięcie na głos przedstawicieli kościelnej hierarchii, którzy od samego początku próbowali przypominać zarówno duchownym, jak i świeckim wiernym podstawowe prawdy Ewangelii odnośnie do migrantów i uchodźców.

Wydaje się, że opisana sytuacja ma również korzenie w nieprzygotowaniu wiernych do spotkania z tego rodzaju doświadczeniem. Dotychczas o migracji mówiło się w Polsce najczęściej w kontekście duszpasterskiej troski o wspólnoty polonijne poza granicami kraju. Istnieją dwa zgromadzenia zakonne zajmujące się duszpasterstwem wśród Polaków na obczyźnie - męskie, Towarzystwo Chrystusowe dla Polonii Zagranicznej i żeńskie Zgromadzenie Sióstr Misjona-

${ }^{2}$ Por. Uchodźca czy migrant? Tlumaczymy różnice $i$ wyjaśniamy ich sens. UNHCR. The UN Refugee Agency/Polska - http://www.unhcr.org/pl/365-plwiadomosci2016uchodzca-czymigrant-tlumaczymy-roznice-i-wyjasniamy-ich-sens-html.html [dostęp: 10.11.2017].

${ }^{3}$ Konwencja dotycząca statusu uchodźców, sporządzona w Genewie dnia 28 lipca 1951 r., rozdz. 1 art. 1 p. 2. „Dziennik Ustaw”. R. 1991 nr 119 poz. 515.

${ }^{4} \mathrm{Na}$ ten temat zob. - M. Prisching: Soziologie der kollektiven Ängste. „Theologisch-praktische Quartalschrift“. Jg. 165: 2017 Heft 4 S. 339-347. 
rek Chrystusa Króla dla Polonii Zagranicznej. Oba swoje patronalne święto obchodzą w ostatnią niedzielę roku liturgicznego w Uroczystość Jezusa Chrystusa Króla Wszechświata. Nadto wspomnieć trzeba, że nie bez znaczenia, również w odniesieniu do tego problemu, pozostaje w Polsce sprawa pełniejszej recepcji nauczania Soboru Watykańskiego II. Podobnie jak w wielu innych kwestiach, jest to ciągle aktualne wezwanie Jana Pawła II, które zawarł w programie przygotowania Kościoła do Jubileuszu Roku 2000. Zapraszając wszystkich do rachunku sumienia, zwracał uwagę, że nie może on ,pominąć także przyjęcia nauki Soboru - tego wielkiego daru Ducha, ofiarowanego Kościołowi u schyłku drugiego tysiąclecia. W jakiej mierze słowo Boże stało się, w pełniejszy sposób, duszą teologii i natchnieniem całego chrześcijańskiego życia, jak tego żądała Konstytucja Dei verbum? [...] Żywotne znaczenie ma też pytanie, które należy zadać o styl relacji między Kościołem a światem. Zalecenia Soboru, zawarte w Konstytucji Gaudium et spes i w innych dokumentach, dotyczące dialogu otwartego, opartego na wzajemnym szacunku i życzliwości, któremu wszakże ma towarzyszyć staranne rozeznanie i odważne świadectwo o prawdzie, pozostają w mocy i wzywają nas do dalszych wysiłków"5.

Podejmując zatem rozważania wokół pastoralnych problemów związanych z natężeniem ruchów migracyjnych, przedstawimy najpierw na podstawie badań socjologicznych proces kształtowania się postaw Polaków wobec migrantów i uchodźców, by następnie przybliżyć główne myśli nauczania Kościoła odnośnie do zjawiska migracji, a wreszcie, na koniec, sformułować niektóre przynajmniej propozycje dla duszpasterstwa.

\section{Dynamika odrzucenia}

Dla zrozumienia wyzwania, jakim dla Kościoła w Polsce są problemy związane z rosnącą falą migracyjną w Europie, ważne jest spojrzenie na proces kształtowania się postaw Polaków wobec migrantów i uchodźców. Badania socjologiczne ostatnich lat bardzo wyraźnie ukazują dynamikę dokonujących się zmian. Centrum Badania Opinii Społecznej [CBOS] od ponad 20 lat prowadzi badania stosunku Polaków do innych narodów ${ }^{6}$. W podsumowaniu wspomnianych badań ze stycznia 2015 roku zauważano, że istnieje generalna zależność,

5 J a n P aw eł I I: List apostolski Tertio millennio adveniente. „L'Osservatore Romano”. Wyd. polskie. R. 15: 1994 nr 12 s. 16 pkt 36.

6 Por. Stosunek do innych narodów. „Komunikat z Badań CBOS” nr 14/2015. Opr. M. O m yła-R u d z k a. Warszawa, styczeń 2015 s. 1. Zob. także - Wewnątrzunijna mobilność obywateli państw trzecich. Raport przygotowany przez Krajowy Punkt Kontaktowy Europejskiej Sieci Migracyjnej w Polsce. Październik 2013. Krajowy Punkt Kontaktowy Europejskiej Sieci Migracyjnej w Polsce Ministerstwo Spraw Wewnętrznych - Departament Polityki Migracyjnej. Red. K. Ł u k a s z c z y k. Warszawa 2013. 
która związana jest poziomem życia konkretnych narodów - im wyższy ich poziom życia, tym większa dla nich sympatia Polaków. Równocześnie obserwowany jest większy dystans wobec nacji „zamieszkujących kraje biedniejsze, charakteryzujących się niższym poziomem życia i stanowiących dla nich negatywną grupę odniesienia"7. W tymże samym podsumowaniu zwraca się jednocześnie uwagę, że stosunek Polaków „do wielu narodów, które niegdyś, w latach dziewięćdziesiątych, darzyliśmy stosunkowo niewielką sympatią, poprawił się - np. do Romów, Rumunów, Ukraińców, Bułgarów czy Białorusinów"8.

W kolejnym raporcie CBOS z czerwca 2015 roku, który przedstawia wyniki badań przeprowadzonych nt. Przybysze z bliska i z daleka, czyli o imigrantach $w$ Polsce, zauważono, że napływ większej liczby imigrantów z państw sąsiedzkich nie spowodował wzrostu napięć i niechęci do nich ${ }^{9}$. W maju 2015 roku ankieterzy CBOS pytali rodaków o ich stosunek do cudzoziemców mieszkających w Polsce. Badano najpierw odczucia Polaków dotyczące liczebności przedstawicieli poszczególnych narodów mieszkających w Polsce. Według respondentów w naszym kraju najwięcej przebywa Ukraińców (70\% wskazało ich jako jedną z trzech najliczniejszych grup), zaś na Wietnamczyków wskazało $26 \%$ badanych. Jako najliczniejszą grupę wskazano też obywateli Unii Europejskiej i Rosji (po 15\%). Również za liczebnie znaczącą grupę w odpowiedziach uznano obywateli pozostałych krajów byłego ZSRR (11\%) oraz innych państw azjatyckich (10\%). Tylko 6\% było zdania, że najliczniejszą grupą są także obywatele państw afrykańskich. Dane pochodzące z Urzędu ds. Cudzoziemców potwierdzają, że najliczniejszą grupę imigrantów stanowią Ukraińcy, a na drugim miejscu znajdują się Wietnamczycy ${ }^{10}$.

W raporcie zauważono, że w sposób widoczny zmniejszył się dystans Polaków wobec obcokrajowców. W stosunku do końca lat dziewięćdziesiątych zmalała o połowę liczba osób przeciwnych temu, aby cudzoziemiec zamieszkał w ich sąsiedztwie, by był ich bliskim współpracownikiem, lekarzem, nauczycielem ich dziecka, szefem w zakładzie pracy czy nawet księdzem w ich parafii ${ }^{11}$.

Gdy chodzi o ocenę wpływu obecności obcokrajowców, to w maju 2015 roku za korzystną Polacy uważali obecność Amerykanów (52\%), Czechów (51\%) i Niemców (50\%), Ukraińców (38\%), Wietnamczyków (33\%), Rosjan (31\%). Obecność obywateli państw Afryki za korzystną uważało także 26\% rodaków.

${ }^{7}$ Tamże, s. 8.

${ }^{8}$ Tamże.

${ }^{9}$ Por. Przybysze z bliska i z daleka, czyli o imigrantach $w$ Polsce. „Komunikat z Badań CBOS” nr 93/2015. Opr. K. Kowalczuk. Warszawa, czerwiec 2015 s. 12.

${ }^{10}$ Por. tamże, s. 4.

${ }^{11}$ Por. tamże, s. 5. 
Jednak tylko $20 \%$ pozytywnie oceniało obecność Turków, a Arabów jedynie 14\%. Większość Polaków negatywnie oceniało obecność w Polsce Turków $(52 \%)$ i Arabów $(62 \%)^{12}$.

Warto jeszcze wspomnieć, że w omawianych badaniach z maja 2015 roku większość Polaków (69\%) z jednej strony zgadza się na zatrudnianie migrantów spoza Unii Europejskiej, zwłaszcza w tych miejscach, gdzie brakuje Polaków gotowych do podjęcia pracy, z drugiej - znacząca większość (86\%) nie zgadza się ze stwierdzeniem, że Polska potrzebuje większej liczby migrantów, co zapewne - jak podkreślają badacze - wynikało wówczas z przekonania, że w Polsce nie brakuje chętnych do podjęcia pracy ${ }^{13}$.

W podsumowaniu badań zauważa się, że ,pomimo częstego przekonania o pozytywnym wpływie większej liczby cudzoziemców, głównie o zaletach różnorodności kulturowej i tolerancji, raczej nie tęsknimy za przetestowaniem modelu społeczeństwa wielokulturowego. Przeważa przekonanie, że chociaż imigracja ma pozytywne skutki gospodarcze, to jednak bezpośrednio na badanych będzie miała ona negatywny wpływ. Warto podkreślić różnice w opiniach na ten temat między mieszkańcami największych miast i mniejszych miejscowości"14.

Poważne zmiany postaw wobec migrantów, a zwłaszcza uchodźców, zaobserwować można na podstawie badań przeprowadzonych przez CBOS w grudniu 2016 roku. W Komunikacie z badań pt. Stosunek Polaków do przyjmowania uchodźców odnotowano, że „ogólne poparcie dla przyjmowania uchodźców spadło w związku z zamachami z listopada 2015 r. i od tego czasu pozostaje właściwie niezmienne. Podobną dynamiką cechuje się stosunek do relokacji imigrantów z Bliskiego Wschodu i Afryki, przybywających przede wszystkim do krajów położonych przy południowych granicach Unii Europejskiej. Zdecydowanie bardziej przychylne nastawienie do uchodźców z Ukrainy utrzymuje się na podobnym poziomie od rozpoczęcia pomiarów"15.

$\mathrm{Na}$ dość ogólnie sformułowane pytanie, które dotyczyło nastawienia do udzielenia pomocy osobom zmuszonym do opuszczenia kraju pochodzenia, najczęstszą postawą w odpowiedziach okazywał się sprzeciw wobec przyjęcia uchodźców (54\%). Znacznie mniejsza grupa respondentów (37\%) deklarowała zgodę na udzielenie im tymczasowego schronienia ${ }^{16}$. We wspomnianych badaniach widać także różnice opinii między osobami należącymi do różnych grup

12 Por. tamże, s. 7.

${ }^{13}$ Por. tamże, s. $10-12$.

${ }^{14}$ Tamże, s. 12-13.

${ }^{15}$ Stosunek Polaków do przyjmowania uchodźców. „Komunikat z Badań CBOS” nr 1/2017. Opr. A. Gło w a c k i. Warszawa, styczeń 2017 s. 1.

${ }^{16}$ Por. tamże, s. 4-5. 
społecznych i wiekowych. Istotna zmiana w stosunku do wcześniejszych badań dokonała się w grupie młodych ludzi (25-44 1.), która w badaniach ze stycznia 2015 roku wykazywała najczęściej sympatię do innych nacji ${ }^{17}$. W grudniowych badaniach z 2016 roku młodzi ludzie byli mniej pozytywnie nastawieni do przyjmowania uchodźców niż starsi - ok. $62 \%$ osób w wieku poniżej 35 lat była temu przeciwna, tymczasem pośród osób starszych było to $48-52 \%$ respondentów. Odnotowuje się również różnice regionalne. Najbardziej sceptycznie do przyjmowania uchodźców są nastawieni mieszkańcy województw: łódzkiego i podkarpackiego (60\% przeciwnych) oraz lubelskiego i opolskiego $(58 \%)$. Najbardziej zaś przychylni są badani z województw: dolnośląskiego, mazowieckiego, pomorskiego i zachodniopomorskiego (49\% przeciwnych przyjmowaniu uchodźców) ${ }^{18}$.

Znacząca zmiana postaw uwidacznia się wtedy, gdy pytania są bardziej szczegółowe. Pytanie wyraźnie określające, że chodzi o osoby z Bliskiego Wschodu i Afryki przybywające do Unii Europejskiej, w odpowiedzi przynosi przewagę deklaracji przeciwnej (68\%) przyjmowaniu tych uchodźców. Jednak $37 \%$ ankietowanych $\mathrm{z}$ tej grupy twierdzi, że powinniśmy pozwolić im na pobyt tymczasowy ${ }^{19}$. Badania wskazują też na wyraźny związek stanowiska dotyczącego przyjmowania uchodźców z poglądami politycznymi. Zdeklarowany wyborca prawicy sprzeciwia się $(75 \%)$ przyjęciu przez Polskę uchodźców z Bliskiego Wschodu i Afryki, a 21\% popiera ten projekt. Bardziej przychylne stanowisko w tej kwestii prezentują wyborcy lewicy, ale i pośród nich ponad połowa $(52 \%)$ deklaruje sprzeciw ${ }^{20}$.

Zupełnie inaczej przedstawia się stosunek Polaków do uchodźców ze wschodniej Ukrainy. Można tutaj obserwować większą przychylność i bardziej pozytywne nastawienie. Aż $57 \%$ badanych uważa, że powinniśmy przyjąć uchodźców ze wschodniej Ukrainy, gdzie trwa konflikt. Nawet wśród respondentów, którzy w ogóle sprzeciwiają się przyjmowaniu uchodźców, jest znaczna grupa (38\%) popierających w tym wypadku takie stanowisko. W raporcie z badań zwraca się uwagę, że analizując stosunek Polaków do uchodźców ze wschodniej Ukrainy, należy również wziąć pod uwagę istnienie bardzo licznej grupy migrantów zarobkowych. Co ważne, jak zaznaczają autorzy raportu, na akceptację odnośnie do przyjmowania uchodźców z Ukrainy mały wpływ ma

${ }^{17}$ Por. Stosunek do innych narodów. „Komunikat z Badań CBOS”, dz. cyt., s. 10.

18 Por. Stosunek Polaków do przyjmowania uchodźców. „Komunikat z Badań CBOS”, dz. cyt., s. 5 .

${ }^{19}$ Por. tamże, s. 8.

${ }^{20}$ Por. tamże, s. 10. Zob. także - I. W i ś n i o w s k a: Aus der Ukraine über Russland nach Polen. „Ost-West. Europäische Perspektiven”. Jg. 17: 2016 Heft 4 S. 252-260; J. K o n i e c z n a - S a ł a m a t i n: W poszukiwaniu miliona Ukraińców. „Więź”. R. 60: 2017 nr 3 (669) s. 78-91. 
identyfikacja polityczna respondentów, zaś poziom przychylności wobec nich, podobnie jak w poprzednich sytuacjach, związany jest m.in. z wiekiem. Badani w wieku 25-34 1. są jedyną grupą wiekową, w której poziom akceptacji nie przekracza połowy $(49 \%)^{21}$.

\section{Przemilczane nauczanie Kościoła}

Można sądzić, że jedną z dostrzeganych w badaniach socjologicznych przyczyn zmiany postaw wobec migrantów, a zwłaszcza uchodźców, obok istotnego udziału w tym procesie mass mediów, jest w pewnym zakresie nieznajomość wśród wiernych treści oficjalnego nauczania Kościoła na ten temat. Już Sobór Watykański II uznaje słuszne prawo osobowe do migracji ${ }^{22}$. Mając na względzie postanowienia zawarte w Powszechnej Deklaracji Praw Człowieka ${ }^{23}$, zwraca uwagę na konieczność wystrzegania się

wszelkiej dyskryminacji w zakresie warunków wynagrodzenia albo warunków pracy wobec robotników, którzy wywodząc się z innego narodu lub kraju, przyczyniają się swoją pracą do postępu gospodarczego określonego narodu albo regionu. Ponadto wszyscy, a szczególnie władze publiczne, powinni ich traktować nie jako narzędzia produkcji, lecz jako osoby i pomagać im w sprowadzeniu do siebie rodzin i w zapewnieniu przyzwoitego mieszkania, a także wspierać ich włączanie się w życie społeczne tego narodu albo kraju, który ich przyjmuje $\mathrm{e}^{24}$.

Sobór podkreśla również, że biskup jako głosiciel wiary na misjach musi uwzględniać te zmiany, które wywołuje m.in. urbanizacja czy migracja ludności ${ }^{25}$. Jednakże zasadniczy przekaz kościelnego nauczania odnośnie do pro-

${ }^{21}$ Por. tamże, s. 11- 13. Zob. także - D. Ha 11, A. M iku $1 \mathrm{ska-J}$ olle s: Uprzedzenia, strach czy niewiedza? Młodzi Polacy o powodach niechęci do przyjmowania uchodźców. Analizy, Raporty, Ekspertyzy. Nr 1/2016. Red. W. Kl a u s. Stowarzyszenie Interwencji Prawnej i Laboratorium Migracji. Warszawa 2016.

22 Konstytucja duszpasterska o Kościele w świecie współczesnym Gaudium et spes. W: Sobór Watykański II. Konstytucje, dekrety, deklaracje. Nowe thumaczenie. Poznań 2002 s. 581 pkt 65.

${ }^{23}$ Artykuł 13 PDPC stwierdza: „1. Każdy człowiek ma prawo swobodnego poruszania się i wyboru miejsca zamieszkania w granicach każdego Państwa. 2. Każdy człowiek ma prawo opuścić jakikolwiek kraj, włączając w to swój własny, i powrócić do swego kraju". - http://www.unesco.pl/ fileadmin/user_upload/pdf/Powszechna_Deklaracja_Praw_Czlowieka.pdf [dostęp: 10.11.2017].

${ }^{24}$ Konstytucja duszpasterska o Kościele w świecie współczesnym Gaudium et spes. W: Sobór Watykański II, dz. cyt., pkt 66 s. 581.

${ }^{25}$ Por. Dekret o misyjnej działalności kościoła Ad gentes divinitus. W: Sobór Watykański II, dz. cyt., s.454 pkt 20 . 
blemów migracyjnych, obok kilku odrębnych dokumentów ${ }^{26}$, znaleźć można w dorocznych Orędziach publikowanych z okazji Światowego Dnia Migranta i Uchodźcy, obchodzonego przez Kościół w drugą niedzielę po Objawieniu Pańskim ${ }^{27}$.

Jan Paweł II, który opublikował dwadzieścia Orędzi (1985-2005), podejmował w nich wiele szczegółowych problemów związanych z migracją. W pierwszym Orędziu z 1985 roku podkreślał, iż ,poszczególne Kościoły partykularne wiedzą, że spoczywa na nich obowiązek należytej troski o tych wszystkich, którzy z jakiegokolwiek powodu są zmuszeni do przebywania poza granicami swojej ojczyzny i własnej wspólnoty etnicznej. Celem tej troski jest włączenie ich w życie Kościoła, z pełnym poszanowaniem ich prawa do wolności”28. W 1992 roku Jan Paweł II poszerzył spektrum swoich uwag dotyczących migracji. Orędziu na ten rok nadał bardzo znamienny tytuł - Kościól wzywa wszystkich ludzi do petniejszej solidarności. Papież zauważył, że „zjawisko migracji jest dziś coraz powszechniejsze, ponieważ wzrasta rozziew pomiędzy poziomem rozwoju gospodarczego, społecznego i politycznego krajów bogatych, których jest coraz mniej a ubogich, których jest coraz więcej. W takiej sytuacji ci, którym udało się przekroczyć granice «państw», mogą to uważać za swego rodzaju sukces, ponieważ mogą zbierać okruchy spadające ze stołów dzisiejszych bogaczy [...] gdy jakiś naród otwiera się odważnie na przyjęcie imigrantów, zostaje wynagrodzony większym dobrobytem i głęboką odnową społeczną, wzbogaca się o nowe zasoby energii, która umożliwia niespotykany rozwój gospodarczy i postęp człowieka"29. W papieskim przesłaniu z 1996 roku widać bardzo zdeterminowaną postawę wobec problemów migracji, skoro wprost powiedział:

${ }^{26}$ Chodzi przede wszystkim o następujące dokumenty - Kongregacji Biskupów: Instrukcja dotycząca duszpasterstwa wśród migrantów De pastorali migratorum cura [22.08.1969 r.]. AAS 61: 1969 s. 614-643. Tłum. pol. za: Posoborowe prawodawstwo kościelne (dokumenty prawno-liturgiczne). Tłum. E. S zt a frowski. T. 2 z 2. Warszawa 1970 s. 177-244 oraz P a pieska Rada ds. Duszpasterstwa Migrantów i Podróżujący ch: Instrukcja Erga migrantes caritas Christi [3.05.2004] - http://rodzinarodzinie.caritas.pl/wp-content/uploads/2016/09/ INSTRUKCJA-ERGA-MIGRANTES-CARITAS-CHRISTI.pdf [dostęp: 10.11.2017].

${ }^{27}$ W latach 1980-1985 ukazywały się one w formie listów ówczesnego sekretarza stanu, kard. Agostina Casarolego. W związku ze wzrostem liczby migrantów na przełomie 20 i 21 w. do blisko 200 mln, a tym samym wagi problemów, Jan Paweł II zdecydował, że od 1985 r. osobiście będzie kierował do Kościoła i świata doroczne orędzie na Światowy Dzień Migranta i Uchodźcy. Tradycje te podjął Benedykt XVI, a kontynuuje obecnie papież Franciszek - por. W. Necel: Wprowadzenie..., dz. cyt., s. 5-6.

${ }^{28}$ Kościoły lokalne wobec emigrantów (1985). W: J a n P aw eł II: Orędzia na Światowy Dzień Migranta i Uchodźcy 1985-2005. Opr. W. N e c e 1. Poznań 2009 s. 15.

${ }^{29}$ Kościót wzywa wszystkich ludzi do petniejszej solidarności (1992). W: J a n P aweł II: Orędzia na Światowy Dzień Migranta i Uchodźcy, dz. cyt., s. 65-66. 
Wzywam Kościoły partykularne, aby pobudzały do refleksji, by udzielały i dostarczały informacji, a przez to pomagały osobom zaangażowanym na polu duszpasterskim i socjalnym w roztropnym działaniu w tej jakże delikatnej i złożonej dziedzinie. Kiedy zrozumienie tego problemu utrudniają przesądy i ksenofobia, Kościół musi wystąpić jako rzecznik braterstwa, wspierając swoje nauczanie gestami, które dają świadectwo prymatu miłości.

Dalej pouczył, że „w Kościele nikt nie jest obcy, a Kościół nie jest obcy dla żadnego człowieka w żadnym miejscu". Przywołując Ewangelię, uświadomił wszystkim, że „człowiek, zwłaszcza człowiek słaby, bezbronny, zepchnięty na margines społeczny, jest sakramentem obecności Chrystusa (por. Mt 25,40.45)". Przypomniał też wymowne zdanie Ewangelii - „Byłem przybyszem, a przyjęliście Mnie” (Mt 25,35), aby następnie stwierdzić: „Zadaniem Kościoła jest nie tylko nieustanne przypominanie tego nauczania Chrystusowej wiary, ale także wskazywanie jego właściwych zastosowań w różnych sytuacjach, które wciąż na nowo powstają w miarę upływu czasu"30.

W następnym roku Jan Paweł II zauważył, że „zjawisko migracji jawi się jako masowy proces, który ogarnia w wielkiej mierze ludzi ubogich i potrzebujących, zmuszonych do opuszczenia własnego kraju przez konflikty zbrojne, trudne warunki ekonomiczne, napięcia polityczne, etniczne i społeczne oraz przez klęski żywiołowe”. Podkreślił także, że „kierunek ruchów migracyjnych uległ jakby odwróceniu. Coraz liczniejsi niechrześcijanie przenoszą się do krajów o tradycji chrześcijańskiej w poszukiwaniu pracy i lepszych warunków życia, przy czym nierzadko czynią to nielegalnie i jako uchodźcy [...]. Kościół ze swej strony poczuwa się do obowiązku niesienia pomocy, niczym dobry Samarytanin, nielegalnym imigrantom i uchodźcom, którzy są współczesną ikoną człowieka ograbionego, pobitego i porzuconego przy drodze do Jerycha (por. Łk 10,30)"31.

Z okazji Wielkiego Jubileuszu roku 2000 papież-rodak przypomniał, że Kościół ,zabiega o to, aby godność każdego człowieka była szanowana, aby imigrant był przyjmowany jako brat oraz by cała ludzkość tworzyła jedną rodzinę, umiejącą rozumnie docenić różne kultury, które ją współtworzą. W Jezusie Bóg przyszedł, aby prosić ludzi o gościnę. Wskazuje nam przez to, że cnotą typową dla osoby wierzącej jest gotowość przyjęcia z miłością drugiego człowieka"32.

${ }^{30}$ Nie wolno łamać ani ignorować praw migranta (1996). W: J a n P a weł II: Orędzia na Światowy Dzień Migranta i Uchodźcy, dz. cyt., s. 82-83.

${ }^{31}$ Wiara człowieka powinna działać przez miłość (1997). W: Ja n Paweł II: Orędzia na Światowy Dzień Migranta i Uchodźcy, dz. cyt., s. 84. 86.

32 Obchody Wielkiego Jubileuszu wezwaniem do zmiany stylu życia (2000). W: Ja n P aw eł I I: Orędzia na Światowy Dzień Migranta i Uchodźcy, dz. cyt., s. 111. 
Podejmując w Orędziu na 2001 roku temat Duszpasterstwo migrantów droga realizacji misji współczesnego Kościoła, Jan Paweł II stwierdził najpierw, że Kościół uznaje prawo każdego człowieka do emigracji, który ma je „w podwójnym aspekcie: mianowicie ma możność opuścić własny kraj oraz udać się do innego w poszukiwaniu lepszych warunków życia. Rzecz jasna, korzystanie z tego prawa musi być odpowiednio uregulowane, ponieważ jego nieuporządkowane stosowanie przynosiłoby szkodę i zagrażało dobru wspólnemu społeczności, które przyjmują migrantów". Następnie zauważył, że

obecność niechrześcijańskich imigrantów w krajach dawnej tradycji chrześcijańskiej jest wyzwaniem dla wspólnot kościelnych. Zjawisko to nieustannie wzbudza w Kościele dzieła miłosierdzia, którego wyrazem jest gościnność i pomoc okazywana braciom i siostrom poszukującym pracy i mieszkania. Jest to w pewien sposób działalność całkiem podobna do tej, jaka prowadzi wielu misjonarzy w krajach misyjnych, zajmując się chorymi, ubogimi, analfabetami. Taki właśnie jest styl działania ucznia Chrystusa: wychodzić naprzeciw oczekiwaniom i potrzebom bliźnich cierpiących niedostatek. Podstawowym celem jego misji jest jednak głoszenie Chrystusa i Jego Ewangelii [...]. Ważne jest, aby dopomagać społecznościom goszczącym migrantów nie tylko w okazywaniu miłosierdzia i gościnności, ale także w otwarciu na spotkanie, na współpracę i dialog 33 .

Bardzo znaczące przesłanie zawiera Orędzie z 2003 roku, w którym papież podkreślił „chrześcijański obowiązek przyjęcia każdego potrzebującego, który puka do naszych drzwi". Znajdujemy w nim bardzo stanowcze stwierdzenia o tym, że „chrześcijanie, coraz bardziej zakorzenieni w Chrystusie, muszą dokładać starań, aby przezwyciężać wszelkie skłonności do zamykania się w sobie oraz dostrzegać w ludziach innej kultury dzieło Boże. Tylko prawdziwa miłość ewangeliczna jest wystarczająco silna, by dopomóc wspólnotom w przejściu od zwykłej tolerancji wobec innych do prawdziwego poszanowania ich odmienności”. Nie ukrywał również, że ,na tej drodze potrzebne jest czasem prorocze słowo, które wskazuje zło i zachęca do dobra. Gdy dochodzi do napięć, wiarygodność Kościoła, głoszącego naukę o fundamentalnym szacunku należnym każdemu człowiekowi, uzależniona jest od moralnej odwagi duszpasterzy i wiernych, którzy potrafią «wszystko postawić na miłość» (NMI, n. 47)"34.

33 Duszpasterstwo migrantów zadaniem współczesnego Kościoła (2001). W: Jan Paweł I I: Orędzia na Światowy Dzień Migranta i Uchodźcy, dz. cyt., s. 118. 121. 124.

${ }^{34}$ Przeciw przejawom rasizmu, ksenofobii i skrajnego nacjonalizmu (2003). W: Jan P aweł I I: Orędzia na Światowy Dzień Migranta i Uchodźcy, dz. cyt., s. 132-134. 
Problem zachowania własnej tożsamości i uznania tożsamości innych osób pojawia się w ostatnim Orędziu Jana Pawła II z roku 2005. Punkt wyjścia papieskich rozważań stanowi stwierdzenie, iż „wszyscy jesteśmy świadomi, że przy spotkaniu osób wywodzących się z różnych kultur dochodzi często do konfliktu tożsamości. Kryje on w sobie także elementy pozytywne. Wchodząc w nowe środowisko, imigrant niejednokrotnie lepiej uświadamia sobie, kim jest, zwłaszcza gdy odczuwa brak osób i wartości, które są dla niego ważne. W naszych społeczeństwach, w których zjawisko migracji stało się globalne, konieczne jest dążenie do właściwej równowagi między zachowaniem własnej tożsamości a uznaniem tożsamości innych. Należy bowiem akceptować istnienie w danym kraju uprawnionej wielości kultur, dbając, aby było to zgodne z ochroną ładu, od którego zależy pokój społeczny i wolność obywateli”.

W sytuacji, w której coraz częściej przychodzi nam żyć w środowiskach pluralistycznych - jak zauważył papież - pojawia się ,potrzeba dialogu między ludźmi różnych kultur, który nie jest jedynie wyrazem tolerancji, ale rodzi sympatię. Jeśli społeczności migrantów i ludność miejscowa tylko żyją obok siebie, prowadzi to zwykle do wzajemnego zamknięcia się kultur, albo też do ustanowienia między nimi relacji czysto zewnętrznych, sprowadzających się wyłącznie do tolerancji. Należałoby więc dążyć do tego, aby kultury wzbogacały się nawzajem. Aby to było możliwe, winny otwierać się na siebie, poznawać się, okazywać sobie autentyczne zrozumienie i życzliwość"35.

Obyczaj publikowania Orędzi z okazji światowego Dnia Migranta i Uchodźcy kontynuował papież Benedykt XVI. Jego przesłanie z 2012 roku wpisuje się w nurt refleksji poprzednika. Zawiera bardzo wyraźne wezwanie do otwarcia się na przybyszów i udzielenia im pomocy: „Uchodźcy proszący o azyl, którzy uciekają przed prześladowaniami, przemocą i sytuacjami stanowiącymi zagrożenie dla ich życia, potrzebują naszego zrozumienia i akceptacji, poszanowania ich ludzkiej godności i ich praw, a także muszą być świadomi swoich obowiązków. Ich cierpienie apeluje do poszczególnych państw i wspólnoty międzynarodowej o wzajemną akceptację, przezwyciężenie lęków i wystrzeganie się różnych form dyskryminacji, a także konkretną solidarność, wyrażającą się m.in. poprzez tworzenie odpowiednich struktur służących przyjmowaniu migrantów i programy osiedleńcze. To wszystko wymaga wzajemnej pomocy regionów, które cierpią, z tymi, które już od lat przyjmują wielką liczbę uciekinierów, a także lepszego współudziału państw w odpowiedzialności”36.

${ }^{35}$ O zachowanie własnej tożsamości i uznanie tożsamości innych (2005). W: Jan Paw eł II: Orędzia na Światowy Dzień Migranta i Uchodźcy, dz. cyt., s. 141.

${ }^{36}$ Orędzie Benedykta XVI na 98. Światowy Dzień Migranta $i$ Uchodźcy 15 stycznia 2012 r.: ,Migracje a nowa ewangelizacja” - http://www.emigracja.chrystusowcy.pl/index.php/ dzie-migranta/2349-papie-benedykt-xvi [dostęp: 10.11.2017]. 
Tę myśl Benedykt XVI rozwinął szerzej w kolejnym Orędziu na rok 2013, stwierdzając:

\begin{abstract}
Wszyscy, którzy emigrują, niosą w sobie uczucia zaufania i nadziei, które ich animują i pokrzepiają w poszukiwaniu najlepszego stylu życia. Jednakże poszukują oni nie tylko polepszenia swojej sytuacji ekonomicznej, społecznej czy politycznej [...]. W rzeczywistości ci, którzy migrują, karmią się nadzieją, że zostaną przyjęci, otrzymają prawdziwą pomoc i znajdą kontakt z osobami, które zrozumieją trudności i tragedię swoich bliźnich, a także dostrzegą w nich różne wartości i potencjał możliwości, jakie w sobie noszą, i będą gotowi do dzielenia się dobrami ludzkimi i materialnymi z tymi, którzy są w nieszczęściu i potrzebie [...]. Migranci i uchodźcy, razem z trudnościami, mogą nawiązać nowe więzi i doświadczyć gościnności, które ich zachęcą do budowania dobrobytu kraju, do którego przybyli, wykorzystując swoje umiejętności zawodowe, swoje dziedzictwo społeczno-kulturowe i często także dając swoje świadectwo wiary, które da impuls wspólnotom o dawnej tradycji chrześcijańskiej, zachęci do spotkania z Chrystusem i zaprosi do poznawania Kościoła ${ }^{37}$.
\end{abstract}

Również papież Franciszek kontynuuje tradycję związaną ze Światowym Dniem Migranta i Uchodźcy. W pierwszym swoim Orędziu na rok 2014 podjął problem często podnoszonych obaw i lęków wobec przybyszy. Zauważył, że „nierzadko bowiem przybycie migrantów, uchodźców, osób ubiegających się o azyl budzi w lokalnych społecznościach podejrzenia i wrogość. Rodzi się strach, że zagrożone będzie publiczne bezpieczeństwo, że powstanie ryzyko utraty tożsamości i kultury, że wzrośnie konkurencja na rynku pracy, a nawet, że pojawią się nowe czynniki przestępczości. Środki społecznego przekazu mogą odegrać na tym polu bardzo odpowiedzialną rolę: to one powinny bowiem przełamywać stereotypy i podawać prawdziwe informacje, w których niekiedy będzie mowa o błędach pewnych ludzi, ale ukazane będą też uczciwość, prawość i wielkoduszność większości. W tym zakresie potrzebna jest zmiana postawy wszystkich wobec migrantów i uchodźców; przejście od postawy obronnej, nacechowanej strachem, brakiem zainteresowania i tendencją do marginalizacji - która ostatecznie odpowiada właśnie «kulturze odrzucania» - do postawy opartej na «kulturze spotkania», jedynej, która potrafi budować świat bardziej sprawiedliwy i braterski, lepszy świat. Również środki przekazu powołane są do

${ }^{37}$ Orędzie Ojca Świętego Benedykta XVI na 99. Światowy Dzień Migranta i Uchodźcy 13 stycznia $2013 r$. - «Migracje: pielgrzymka wiary i nadziei» - http://www.emigracja.chrystusowcy.pl/ index.php/dzie-migranta/2348-ordzie-ojca-witego-benedykta-xvi-na-99-wiatowy-dzie-migrantai-uchodcy-qmigracje-pielgrzymka-wiary-i-nadzieiq-13-stycznia-2013-r [dostęp: 10.11.2017]. 
włączenia się w to «nawrócenie postaw» i do sprzyjania tej zmianie nastawienia do migrantów i uchodźców"38.

Podejmując w 2015 roku hasło: Kościót bez granic matka wszystkich, papież Franciszek w kolejnym Orędziu skupia się na konieczności kształtowania właściwych postaw członków kościelnej wspólnoty wobec migrantów i uchodźców. Przypomina, że

Kościół bez granic, matka wszystkich, szerzy w świecie kulturę przyjmowania i solidarności, zgodnie z którą nikogo nie wolno uważać za niepotrzebnego, będącego nie na swoim miejscu czy do odrzucenia. Jeżeli wspólnota chrześcijańska rzeczywiście żyje swoim macierzyństwem, to umacnia, ukierunkowuje i wskazuje drogę, cierpliwie towarzyszy, staje się bliska przez modlitwę i przez dzieła miłosierdzia. Dziś to wszystko nabiera szczególnego znaczenia. Bowiem w epoce tak rozległych migracji wielka liczba osób opuszcza swoje rodzime miejsca i podejmuje niebezpieczną podróż nadziei, z bagażem pełnym pragnień i lęków, w poszukiwaniu bardziej ludzkich warunków życia. Nierzadko jednak te ruchy migracyjne wzbudzają nieufność i wrogość, nawet we wspólnotach kościelnych, zanim jeszcze pozna się historie życia, prześladowań czy nędzy osób, których to dotyczy. W takim wypadku podejrzenia i uprzedzenia stają $\mathrm{w}$ sprzeczności z biblijnym przykazaniem, by przyjmować z szacunkiem i solidarnością przybysza będącego w potrzebie ${ }^{39}$.

Temat: Migranci i uchodźcy sa dla nas wyzwaniem. Odpowiedź daje Ewangelia miłosierdzia, zdominował treść papieskiego Orędzia w 2016 roku. Mówiąc o konieczności przyjmowania, Franciszek nie ukrywał, że „obecność migrantów i uchodźców staje się poważnym wyzwaniem dla wielu społeczeństw, które ich przyjmują. Muszą one stawiać czoło nowym realiom, które mogą okazać się niewygodne, jeśli nie będą należycie umotywowane, zorganizowane i regulowane. Jak to zrobić, by integracja stała się wzajemnym ubogaceniem, by otworzyła pozytywne szlaki wspólnotom i zapobiegała ryzyku dyskryminacji, rasizmu, skrajnego nacjonalizmu lub ksenofobii?” Podejmując problem, papież zadał kolejne pytanie, na które udzielił odpowiedzi: „W obliczu tych problemów, czy Kościół może działać inaczej, niż wzorując się na przykładzie i słowach Jezusa Chrystu-

38 Orędzie Ojca Świętego Franciszka na Światowy Dzień Migranta i Uchodźcy 2014 r. »Migranci i uchodźcy: ku lepszemu światu« - http://w2.vatican.va/content/francesco/pl/messages/ migration/documents/papa-francesco_20130805_world-migrants-day.html [dostęp: 10.11.2017].

${ }^{39}$ Orędzie Ojca Świętego Franciszka na Światowy Dzień Migranta i Uchodźcy 2015 r. - http:// w2.vatican.va/content/francesco/pl/messages/migration/documents/papa-francesco_20140903 world-migrants-day-2015.html [dostęp: 10.11.2017]. 
sa? Odpowiedzią Ewangelii jest miłosierdzie”. Ojciec Święty przypomniał przy okazji, iż „objawienie biblijne zachęca do przyjęcia obcokrajowca, zapewniając, że tak czyniąc, otwiera się drzwi Bogu, a w obliczu drugiej osoby dostrzega się rysy twarzy Jezusa Chrystusa" 40 .

Przygotowane na rok 2018 Orędzie pt. Przyjmować, chronić, promować $i$ integrować imigrantów $i$ uchodźców, papież Franciszek rozpoczął cytatem z Księgi Kapłańskiej - „Przybysza, osiadłego wśród was, będziecie uważać za tubylca. Będziesz go miłował jak siebie samego, bo i wy byliście przybyszami w ziemi egipskiej. Ja jestem Pan, Bóg wasz!” (Kpł 19,34). Przywołanie biblijnego tekstu stanowi swoiste wprowadzenie do stwierdzenia, że „Każdy cudzoziemiec, który puka do naszych drzwi, jest okazją do spotkania z Jezusem Chrystusem, utożsamiającym się z cudzoziemcem przyjętym lub odrzuconym każdej epoki (por. Mt 25,35.43). Pan powierza macierzyńskiej miłości Kościoła każdą osobę ludzką zmuszoną do opuszczenia swojej ojczyzny w poszukiwaniu lepszej przyszłości. Troska taka musi być wyrażona w sposób konkretny na każdym etapie doświadczenia migracyjnego: od wyruszenia w drogę, od początku do końca. To wielka odpowiedzialność, którą Kościół pragnie dzielić ze wszystkimi wierzącymi oraz ludźmi dobrej woli, którzy są powołani do odpowiadania na wiele wyzwań stawianych przez współczesną migrację z wielkodusznością, skwapliwie, mądrze i dalekowzrocznie, każdy według swoich możliwości. W tym kontekście pragnę potwierdzić, że «nasza wspólna odpowiedź mogłaby być osnuta na czterech czasownikach: przyjmować, chronić, promować i integrować»"41.

Ojciec Święty wyraźnie nawiązał tutaj do globalnego paktu na rzecz migracji i globalnego paktu na rzecz uchodźców. Jak wyjaśnia bp Krzysztof Zadarko, przewodniczący Rady ds. Migracji, Turystyki i Pielgrzymek Konferencji Episkopatu Polski i zarazem delegat episkopatu ds. migracji, ,jest to program przygotowywany przez ONZ, w który - z bardzo konkretnymi propozycjami dwudziestu punktów pastoralnego podejścia do migrantów i uchodźców - włączyła się Stolica Apostolska. Przede wszystkim wybrzmiewają tam cztery słowa, które padły już w Orędziu na Światowy Dzień Migranta i Uchodźcy 2018: przyjęcie, ochrona, promocja i integracja”. Wspomniane „20 punktów przygotowanych przez Stolicę Apostolską będzie sugestią dla episkopatów na całym

40 Orędzie Ojca Świętego Franciszka na Światowy Dzień Migranta i Uchodźcy 2016 r. (17 stycznia 2016): Migranci i uchodźcy sa dla nas wyzwaniem. Odpowiedź daje Ewangelia mitosierdzia - http://w2.vatican.va/content/francesco/pl/messages/migration/documents/papa-fran cesco_20150912_world-migrants-day-2016.html [dostęp: 10.11.2017].

${ }^{41}$ Orędzie Papieża Franciszka na Światowy Dzień Migranta i Uchodźcy 2018 r. (14 stycznia 2018):Przyjmować, chronić, promować i integrować imigrantów i uchodźców - http://w2.vatican. $\mathrm{va} /$ content/francesco/pl/messages/migration/documents/papa-francesco_20170815_worldmigrants-day-2018.html [dostęp: 10.11.2017]. 
świecie i pomocą w budowaniu duszpasterskich programów opieki nad uchodźcami" $" 42$.

Papież, po omówieniu w Orędziu szczegółowo wszystkich czterech słów, zadeklarował, że „Zgodnie ze swoją tradycją duszpasterską, Kościół jest gotów aktywnie zaangażować się $\mathrm{w}$ realizację wszystkich proponowanych powyżej inicjatyw, ale aby uzyskać pożądane rezultaty niezbędny jest wkład wspólnoty politycznej oraz społeczeństwa obywatelskiego, każde zgodnie z właściwą im odpowiedzialnością"43.

\section{Aby zrozumieć i pomóc}

W związku ze zmieniającą się sytuacją społeczno-ekonomiczną i polityczną świata problem migrantów i uchodźców będzie stale aktualny. Nawet jeśli wojna w Syrii niebawem się skończy, to fala migracyjna nie wygaśnie. Większość bowiem ludzi docierających dzisiaj do Europy przybywa z Afryki Subsaharyjskiej, a także, coraz częściej z Dalekiego Wschodu. Kościół zatem, nie oglądając się na polityków, musi podejmować coraz szerzej działalność, która będzie otwierała ludzi na migrantów i uchodźców. Zaprezentowane wcześniej wyniki badań pokazują, że w Polsce ten problem jest palący, choć w kraju o tak dominującej liczbie katolików można by oczekiwać większej wrażliwości na ludzkie tragedie.

Zacząć trzeba od recepcji kościelnego nauczania związanego z tematyką migracyjną. W zaprezentowanej wcześniej relacji na ten temat mieliśmy okazję poznać całe jej bogactwo, a zarazem bardzo jednoznacznie stawiane wiernym wymagania. To właśnie całkowity brak znajomości tego nauczania, zarówno pośród duchownych, jak i świeckich, pozwala bezrefleksyjnie poddawać się prowadzonemu przez polityków i mass media procesowi zarządzania ludzkimi lękami i strachem. Ta szczególna edukacja powinna biec różnymi drogami, nie tylko $\mathrm{w}$ formie pouczania $\mathrm{z}$ ambony i w formie listów pasterskich, ale także poprzez inicjowanie szerokiej debaty, w której byłaby możliwość wysłuchania i przekazania różnych racji. Ciągle słabością Kościoła w Polsce jest właśnie ów sposób wzajemnego komunikowania. O ważnych sprawach się nie rozmawia, a jedynie ogłasza oficjalne komunikaty, w których często brakuje podstawowego uzasadnienia prezentowanych opinii.

W tym kontekście warto poprzeć, zainaugurowaną 27 września 2017 roku papieską inicjatywę „Share the Journey”, która zachęca do wysłuchania emi-

42 Nie tylko korytarze humanitarne. Bp Zadarko o nowych inicjatywach Kościoła na rzecz uchodźców - http://laboratorium.wiez.pl/2017/10/16/nie-tylko-korytarze-humanitarne-bp-zadarko -o-nowych-inicjatywach-kosciola-na-rzecz-uchodzcow/ [dostęp:10.11.2017].

${ }^{43}$ Orędzie Papieża Franciszka na Światowy Dzień Migranta i Uchodźcy 2018 r., dz. cyt. 
grantów, mówiących o swoich losach i przyczynach ucieczki z własnego kraju. Pozwala to lepiej zrozumieć wyzwania i potrzeby osób, które przybywają do Europy. Jak mówił bp Zadarko: „Wsłuchać się w człowieka, migranta i uchodźcę. W człowieka, który z różnych powodów jest zmuszony do ucieczki z domu, który szuka schronienia i normalnego życia. Ta akcja Caritas Internationalis, Caritas Europa i Caritas poszczególnych krajów, w którą włącza się papież Franciszek, jest apelem, by właśnie z takim podejściem pomagać uchodźcom"44.

Kolejną sprawą jest brak szerszego przekazu informacji na temat podejmowanych inicjatyw względem migrantów i uchodźców. Są realizowane bardzo ciekawe projekty i pomysły, ale mało kto o nich słyszał. Tymczasem wiedza o nich pomaga w kształtowaniu postaw i propagowaniu wzorców zachowań, co bywa niekiedy skuteczniejszym działaniem niż wyłącznie przekaz werbalny ${ }^{45}$. Owo propagowanie wzorców zachowań jest niezmiernie ważne szczególnie w odniesieniu do młodego pokolenia Polaków, którzy - jak wskazują na to ostatnie badania - są grupą wiekową wykazującą najniższy poziom akceptacji wobec migrantów i uchodźców.

Zdecydowania wymaga realizacja projektu utworzenia w Polsce korytarzy humanitarnych, tym bardziej że nie ma tutaj mowy o przypadkowym i nieprzemyślanym przyjmowaniu uchodźców. Potrzebna jednak jest w tym wypadku zgoda władz państwowych, które mają odpowiednie służby i własną politykę migracyjną. Jak podkreślają osoby zaangażowane w to dzieło „niezwykle ważnym aspektem korytarzy humanitarnych jest ich ekonomiczna niezależność. Budżetu państwa nic nie kosztują, ponieważ jest to inicjatywa w całości finansowana przez stowarzyszenia, które ją promują. Przyjęcie uchodźców możliwe jest dzię-

${ }^{44}$ Nie tylko korytarze humanitarne. Bp Zadarko o nowych inicjatywach Kościoła na rzecz uchodźców, dz. cyt.

45 Jedną z takich szerzej nieznanych inicjatyw było Oświadczenie Rady Spolecznej przy Metropolicie Poznańskim w sprawie uchodźców i migrantów z 11.1.2017 $\mathrm{r}$. w którym pośród końcowych wniosków, m.in. można przeczytać: „Zachowania dyskryminujące przybyszów poszukujących w Polsce swojej nowej ojczyzny są niechrześcijańskie i sprzeciwiają się tradycji polskiej gościnności oraz chrześcijańskiej tożsamości naszego narodu. Coraz pilniejsza staje się potrzeba przygotowania wolontariuszy gotowych pomagać uchodźcom i migrantom. Wsparcia wymagają liczne istniejące już inicjatywy, takie jak np. Polskiej Sekcji „Kościoła w Potrzebie”, czy „Caritas Polska”, które m.in. uruchomiły program pomocy dla uchodźców syryjskich i mieszkańców krajów sąsiadujących z Syrią, zmagających się ze skutkami masowego napływu uciekających przed wojną i głodem. Potrzebne jest wsparcie dla programu „Rodzina Rodzinie", który polega na objęciu patronatem i pomocą materialną konkretnych rodzin syryjskich uchodźców lub mieszkańców Libanu i Jordanii. Z uznaniem należy odnieść się do dokonań pozakościelnych organizacji charytatywnych takich, jak „Polska Akcja Humanitarna”, czy „Polskie Centrum Pomocy Międzynarodowej” - http://www.archpoznan.pl/content/view/ 4253/220/ [dostęp: 10.11.2017]. 
ki szerokiej sieci wolontariuszy" ${ }^{46}$. Tym bardziej niezrozumiały jest upór władz państwowych, które ciągle odmawiają zgody na realizację tego projektu, a ze strony hierarchii kościelnej zbytnia uległość wobec tych decyzji. Chodzi tutaj przecież o zachowanie przynajmniej minimum wiarygodności chrześcijańskiej.

W odniesieniu do migrantów zarobkowych, m.in z Ukrainy, istnieje potrzeba pełniejszego rozwinięcia sieci ośrodków duszpasterskich obu obrządków, gotowych spełniać posługę wobec katolików pochodzących z tamtych terenów. Nie chodzi wyłącznie o zapewnienie możliwości uczestnictwa w nabożeństwach, ale o szeroką opiekę i pomoc w wielu codziennych sprawach. Przykładem może być duszpasterstwo drugiej co do wielkości grupy wietnamskich migrantów, które prowadzą Księża Werbiści. Aby je usprawnić, sprowadzili nawet do Polski swoich współbraci zakonnych z Wietnamu.

$\mathrm{Na}$ koniec, w sytuacji sporego zagubienia wiernych w sprawach związanych z kwestią wzmożonego napływu migrantów i uchodźców, warto sformułować postulat odwagi w wypełnianiu zarówno przez duchownych, jak i świeckich wiernych funkcji prorockiej, do czego zresztą wzywał Jan Paweł II w Orędziu na Światowy Dzień Migranta i Uchodźcy $2003 r$. Wydaje się, że przykładem takiej postawy może być homilia ks. arcybiskupa Stanisława Gądeckiego, który 2 lipca 2017 roku podczas odpustu Matki Bożej Ucieczki Grzeszników w Wieleniu, powiedział: ,[...] nasza gościnność wobec uchodźców i migrantów. W tej kwestii kierunek chrześcijaninowi ukazuje Jezus a nie postanowienia polityki, ekonomii czy kultury. Jezus zaś mówi: «Byłem głodny, a daliście Mi jeść; byłem spragniony, a daliście Mi pić; byłem przybyszem, a przyjęliście Mnie» (Mt 25,35). Wyjście naprzeciw temu Jezusowemu wezwaniu nie jest proste. W dzisiejszych czasach bowiem ruchy migracyjne wciąż się nasilają we wszystkich obszarach naszej planety. Uchodźcy i osoby uciekające ze swojej ojczyzny są wyzwaniem dla jednostek i społeczeństw, gdyż kwestionują ich tradycyjny sposób życia, a niekiedy naruszają horyzont kulturowy i społeczny, z którym się stykają [...]. Kościół radzi nam pokonywanie granic i przejścia od postawy obronnej, nacechowanej strachem, brakiem zainteresowania, tendencją do marginalizacji do postawy opartej na «kulturze spotkania», jedynej, która potrafi budować świat bardziej sprawiedliwy i braterski" ${ }^{47}$.

${ }^{46}$ M. S i g n i fre di: Korytarze humanitarne - bezpieczeństwo i solidarność. „Więź”. R. 60: 2017 nr 3 (669) s. 150.

${ }^{47}$ Abp Gądecki: w sprawie uchodźców kierunek wskazuje Jezus, nie politycy - http://episkopat. pl/abp-gadecki-w-sprawie-uchodzcow-kierunek-wskazuje-jezus-nie-politycy/ [dostęp: 10.11.2017]. 


\section{Bibliografia}

Abp Gadecki: w sprawie uchodźców kierunek wskazuje Jezus, nie politycy - http://episko pat.pl/abp-gadecki-w-sprawie-uchodzcow-kierunek-wskazuje-jezus-nie-politycy/ [dostęp: 10.11.2017].

Hall D., Mikulska-Jolles A.: Uprzedzenia, strach czy niewiedza? Młodzi Polacy o powodach niechęci do przyjmowania uchodźców. Analizy, Raporty, Ekspertyzy. Nr 1/2016. Red. W. Klaus. Stowarzyszenie Interwencji Prawnej i Laboratorium Migracji. Warszawa 2016.

Jan Paweł II: List apostolski Tertio millennio adveniente. „L'Osservatore Romano”. Wyd. polskie. R. 15: 1994 nr 12 s. 4-22.

Jan Paweł II: Orędzia na Światowy Dzień Migranta i Uchodźcy 1985-2005. Opr. W. Necel. Poznań 2009.

Kongregacja Biskupów: Instrukcja dotycząca duszpasterstwa wśród migrantów De pastorali migratorum cura [22.08.1969 r.]. AAS 61: 1969 s. 614- 643. Tłum. pol. za: Posoborowe prawodawstwo kościelne (dokumenty prawno-liturgiczne). Tłum. E. Sztafrowski. T. 2 z 2. Warszawa 1970 s. 177-244.

Konieczna-Sałamatin J.: W poszukiwaniu miliona Ukrainców. „Więź“. R. 60: 2017 nr 3 (669) s. 78-91.

Konwencja dotyczqca statusu uchodźców, sporządzona w Genewie dnia 28 lipca 1951 r., rozdz. 1 art. 1 p. 2. „Dziennik Ustaw”. R. 1991 nr 119 poz. 515.

Necel W.: Wprowadzenie. Jesteśmy przybyszami i osadnikami. W: Jan Paweł II: Orędzia na Światowy Dzień Migranta i Uchodźcy 1985-2005. Opr. W. Necel. Poznań 2009 s. $5-13$.

Nie tylko korytarze humanitarne. Bp Zadarko o nowych inicjatywach Kościoła na rzecz uchodźców - http://laboratorium.wiez.pl/2017/10/16/nie-tylko-korytarze-humanitarne-bpzadarko-o-nowych-inicjatywach-kosciola-na-rzecz-uchodzcow/ [dostęp:10.11.2017].

Orędzie Benedykta XVI na 98. Światowy Dzień Migranta i Uchodźcy 15 stycznia 2012 r.: „Migracje a nowa ewangelizacja” - http://www.emigracja.chrystusowcy.pl/index.php/ dzie-migranta/2349-papie-benedykt-xvi [dostęp: 10.11.2017].

Orędzie Ojca Świętego Benedykta XVI na 99. Światowy Dzień Migranta i Uchodźcy 13 stycznia 2013 r. - »Migracje: pielgrzymka wiary i nadziei« - http://www.emigracja. chrystusowcy.pl/index.php/dzie-migranta/2348-ordzie-ojca-witego-benedykta-xvi-na-99-wiatowy-dzie-migranta-i-uchodcy-qmigracje-pielgrzymka-wiary-i-nadzieiq-13stycznia-2013-r [dostęp: 10.11.2017].

Orędzie Ojca Świętego Franciszka na Światowy Dzień Migranta i Uchodźcy 2014 r. »Migranci i uchodźcy: ku lepszemu światu« - http://w2.vatican.va/content/francesco/pl/mes sages/migration/documents/papa-francesco_20130805_world-migrants-day.html [dostęp: 10.11.2017].

Orędzie Ojca Świętego Franciszka na Światowy Dzień Migranta i Uchodźcy 2015 r. http://w2.vatican.va/content/francesco/pl/messages/migration/documents/papa-france sco_20140903_world-migrants-day-2015.html [dostęp: 10.11.2017].

Orędzie Ojca Świętego Franciszka na Światowy Dzień Migranta i Uchodźcy 2016 r. (17 stycznia 2016): Migranci i uchodźcy sa dla nas wyzwaniem. Odpowiedź daje Ewangelia milosierdzia - http://w2.vatican.va/content/francesco/pl/messages/migration/docu ments/papa-francesco_20150912_world-migrants-day-2016.html [dostęp: 10.11.2017]. 
Orędzie Papieża Franciszka na Światowy Dzień Migranta i Uchodźcy 2018 r. (14 stycznia 2018):Przyjmować, chronić, promować i integrować imigrantów i uchodźców http://w2.vatican.va/content/francesco/pl/messages/migration/documents/papa-france sco_20170815_world-migrants-day-2018.html [dostęp: 10.11.2017].

Papieska Rada ds. Duszpasterstwa Migrantów i Podróżujących: Instrukcja Erga migrantes caritas Christi [3.05.2004] - http://rodzinarodzinie.caritas.pl/wp-content/uploads/2016/09/ INSTRUKCJA-ERGA-MIGRANTES-CARITAS-CHRISTI.pdf [dostęp: 10.11.2017].

Prisching M.: Soziologie der kollektiven Ängste. „Theologisch-praktische Quartalschrift”. Jg. 165: 2017 Heft 4 S. 339-347.

Przybysze z bliska i z daleka, czyli o imigrantach w Polsce. „Komunikat z Badań CBOS” nr 93/2015. Opr. K. Kowalczuk. Warszawa, czerwiec 2015.

Signifredi M.: Korytarze humanitarne - bezpieczeństwo i solidarność. „Więź”. R. 60: 2017 nr 3 (669) s. 147-152.

Sobór Watykański II: Konstytucja duszpasterska o Kościele w świecie współczesnym Gaudium et spes. W: Sobór Watykański II. Konstytucje, dekrety, deklaracje. Nowe tłumaczenie. Poznań 2002 s. 526-606.

Stosunek do innych narodów. „Komunikat z Badań CBOS” nr 14/2015. Opr. M. Omyła-Rudzka. Warszawa, styczeń 2015.

Stosunek Polaków do przyjmowania uchodźców. „Komunikat z Badań CBOS” nr 1/2017. Opr. A. Głowacki. Warszawa, styczeń 2017.

Uchodźca czy migrant? Tlumaczymy różnice $i$ wyjaśniamy ich sens. UNHCR. The UN Refugee Agency/Polska - http://www.unhcr.org/pl/365-plwiadomosci2016uchodzca-czymigrant-tlumaczymy-roznice-i-wyjasniamy-ich-sens-html.html [dostęp: 10.11.2017].

Wewnatrzunijna mobilność obywateli państw trzecich. Raport przygotowany przez Krajowy Punkt Kontaktowy Europejskiej Sieci Migracyjnej w Polsce. Październik 2013. Krajowy Punkt Kontaktowy Europejskiej Sieci Migracyjnej w Polsce Ministerstwo Spraw Wewnętrznych - Departament Polityki Migracyjnej. Red. K. Łukaszczyk. Warszawa 2013.

Wiśniowska I.: Aus der Ukraine über Russland nach Polen. „Ost-West. Europäische Perspektiven”. Jg. 17: 2016 Heft 4 S. 252-260.

\section{STRESZCZENIE \\ Migracja wyzwaniem dla Kościoła w Polsce}

Rosnąca od kilku lat fala migracyjna w Europie jest wyzwaniem nie tylko dla polityków i ekonomistów, ale także dla Kościoła w Polsce, który dotąd w takim zakresie nie zmagał się z tym problemem. Jego dotychczasowe doświadczenia związane były przede wszystkim z duszpasterstwem Polaków przebywających na emigracji w wielu państwach świata. Artykuł podejmuje rozważania wokół pastoralnych problemów związanych z natężeniem ruchów migracyjnych. Przedstawia na podstawie badań socjologicznych zmiany postaw Polaków wobec migrantów i uchodźców, a następnie przybliża główne myśli nauczania Kościoła odnośnie do zjawiska migracji. W końcowej części podejmuje próbę sformułowania propozycji, które mogą stać się impulsem dla polskiego duszpasterstwa.

Słowa kluczowe: migranci, uchodźcy, Kościół w Polsce, duszpasterstwo migrantów 


\section{SUMMARY \\ Migration as a Challenge for the Church in Poland}

The current growing migration wave in Europe has been a challenge not only for politicians and economists, but also for the Church in Poland, which, so far, has not struggled in this area. Her past experience was mainly related to the pastoral care of Poles living in exile in many countries of the world. The article deals with pastoral problems related to the intensity of migration movements. It also shows, on the basis of sociological research, changes in the attitudes of Poles towards migrants and refugees, and then introduces the main ideas of the Church's teaching on the phenomenon of migration. In the final part, the article tries to formulate proposals that could used as an impulse for the Polish pastoral ministry.

Keywords: migrants, refugees, Church in Poland, pastoral care of migrants 